\title{
Escape from and Replay of Racial Wounds in "Beloved"
}

\author{
Mengjia Li \\ Department of English Language, College of Foreign Languages and Cultures, Xiamen University, Xiamen City, Fujian Province, China
}

Email address:

limengjia_1994@163.com

\section{To cite this article:}

Mengjia Li. Escape from and Replay of Racial Wounds in "Beloved". International Journal of Literature and Arts. Vol. 3, No. 6, 2015, pp. 162-165. doi: 10.11648/j.ijla.20150306.16

\begin{abstract}
Morrison's "Beloved" chronicles the brutality of slavery in North America as well as deep trauma to the black community. The abolishment of slavery failed to grant the black and their descents a relief, on the contrary, it produces a more severe post-traumatic stress, disrupting the normal life and the spiritual world of the survivors. Faced with the emotional experience of trauma, many victims choose to escape, but no matter how hard they try, the painful memories still replay in various forms and haunt them. The author analyzes the symptoms of the characters, showing the inability and struggling of the black community in the shadow of trauma and persecution.
\end{abstract}

Keywords: Racial Trauma, Symptoms, Escape, Replay

\section{Trauma Escape}

In Toni Morrison's "Beloved" there are a lot of writing about trauma with following 3 aspects, avoiding trauma, trauma replay and dilemma about trauma narrating. Slavery trauma experience makes victims not wanting to face the pain of the past, the wounds left in individual consciousness forces him or her to face the reality nonetheless. This contradiction is one of the most typical symptoms of trauma.

From trauma critic's perspective, trauma is kind of psychological injury. "With exposure to the impact of trauma, an individual may experience sustained emotional panic, anger, evil feeling and other mutation in cognition or behaviour. Such symptom in psychology is known as Post Trauma Stress Disorder (PTSD)." [1] In order to escape from trauma interference, slaves often take evasive way to protect themselves. In "Beloved" this is largely shown by Denver's hearing loss, illusion and traumatic re-memories.

\subsection{Loss of Hearing and Illusion}

Sethe infanticide event brought endless fear to the children growth. This seems to be a traumatic event caused by family violence, but in fact, by ethnic trauma. Sethe had been a slave, suffered inhuman experience, especially a lot of humiliation as a female slave. So when slave owners tried to catch Sethe and her children, she would rather kill the children than letting them be slaves. This crazy behaviour reflected in a sense her helpless and very deep maternal love to her children.

Unfortunately, her children did not understand their mother's difficulties, even though childhood physical trauma has healed, their psychological trauma was not eliminated. Buglar and Howard grew up always fearful of their home, and ran away from home at the age of thirteen. Not wanting to hear the fact that her mother brutally killed their children, Denver made herself deaf, dodging the contempt of community to her and her family. This hearing loss is a symptom of trauma, not physical disease, but rather a subjective reaction to the trauma.

Illusion is another manifestation of Denver's trauma. The wandering of her brother exacerbated her symptom. She feared loneliness, she had illusion and believed that's true. "She cut my head off every night..... That when she cuts it off it'll be done right; it won't hurt. After she does it I lie there for a minute with just my head. Then she carries it downstairs to braid my hair. "[2] Denver's hallucination is just a replay of the scenario of Sethe's killing baby. Human being has irritant reaction to stimulus, sometimes with a lag, in the forms hallucinations, dreams, intrusive thoughts or behaviour."[3] Sethe infanticide event invaded in Denver's consciousness, greatly impacts her feeling to her mother, "I spent all of my outside self loving Ma'am so she wouldn't kill me." [4] The fear of this absurd idea is just the reaction of Denver's psychological trauma. Slavery racial wounds spread over the home, separated the mother and children, put a loving mother into isolated and embarrassing position. 


\subsection{Re-memory}

In order to escape from trauma and nightmare, re-memory of the past is a way to escape the trauma of victims. The tobacco tin on Paul D's chest is a symbol of his delicate relationship with the traumatic memory.

In "Sweet House" we witnessed Paul - D lost the most basic freedom of movement after Hale went crazy and Sixo got scorched. After a long and torturing journey Paul - D arrived at Sethe's house, he put the pain and trauma suffered before all to the tobacco tin buried in his chest, its lid rusted shut. "he had shut down a generous portion of his head, operating on the part that helped him walk, eat, sleep, sing." [5] Otherwise, Hale' painted faces, Sixo's laughing before his death, those trembling in underground cage would occupy his whole mind. Paul $\bullet \mathrm{D}$ understood if not sealed in the past, the trauma would hinder him to face the reality of life.

But sealing memory is not the most effective way to eliminate trauma. In some unconscious state, traumatic memories still take advantage of. When he saw Sethe, wholehearted surprises and familiar intimacy makes "The closed portion of his head opened like a greased lock." [6] When reminisced with Sethe, who were exhumed from traumatic experience, Paul - D immersed in trauma narrative. He felt really embarrassed before Sethe when he thought about his own humiliating experience. Eventually, Beloved's shouting entered and destroyed Paul - D's effort to escape from trauma. Whether he slept in the living room, kitchen or pantry, full trauma of the past stayed around and controlled him. His pain and despair deepened his sense of shame, forcing him to leave the Sethe's home where he originally wanted to stay. After leaving, Paul $-\mathrm{D}$ tobacco tin has been opened, "His tobacco tin, blown open, spilled contents that floated freely and made him their play and prey."[7] Traumatic memories all gushed out, Paul $\bullet$ D felt frustration, this time he has completely reduced to slaves of the past, no longer struggling to escape.

\section{The Replay of Trauma}

Morrison said: "I thought this has got to be the lest read of all the books I'd written because it is about something that the characters don't want to remember, I don't want to remember, black people don't want to remember, white people don't want to remember. I mean, it's national amnesia" [8]. "National Amnesia" reflects people trying to escape from history, slavery has always been to bring racial wounds. Although slavery had been abolished, but the pain it brought to the black community stayed. Therefore, in "Beloved", Morrison replayed the trauma at black community level as well as Sethe's personal level.

Beloved is a mysterious figure, and there are different opinions around it in academia. From the plot, it is about a darling child was killed by its mother, the soul returned back to the world asking for missing maternal love; but in a deeper sense, it's about the black slaves trauma. As Morrison herself said, "She is a spirit on one hand, literally she is what Sethe thinks she is, her child returned to her from the dead. And she must function like that in the text. She is also another kind of dead which is not spiritual but flesh, which is, a survivor from the true, factual slave ship. She speaks a language, a traumatized language, of her own experience"[9] Judging from the surface the cause of Beloved's death is Sethe's willful killing, yet in fact, it is derived from the mother suffered from racial trauma. A strong desire to protect her children made Sethe willing to try any extreme ways which could possibly save her children being brutalized by slavery. Sethe's seemingly irrational behaviour actually shows slavery is even worse than death. Beloved's tragedy is not a single case, but is the epitome of fate for all black slaves.

Beloved is a historical incarnation racial wounds, it incessantly haunted everyone in the novel, and could not be eliminated. Beloved's revenant identity helps to break the chronological barriers, in that how the story is narrated. In conversation with Sethe, the Beloved pries Sethe with various questions "Where your diamonds?" "Your woman she never fix up your hair?" "Where your Earrings "...... these questions evoked painful memories to Sethe. When thinking of being abused by whites her husband Hale was driven crazy; her mother never feed her and her siblings, but was forced to do hard labour work until finally got hanged to death; when running away she witnessed corpses in the tree ...... Beloved's return forcibly opened Sethe painful past, who had been trying to forget.

Similar to Sethe, Paul - D's traumatic re-memories could not escape the control from Beloved. "The absence of history marker to remind us never to let the atrocity happen again. For its absence has neither erased nor diminished its pain; rather, it reminds us only of itself: of what is missing." [10] Paul $\bullet$ D and Beloved's sexual relationship showed Paul •D's resistance and Beloved's invasion. Paul $\bullet \mathrm{D}$ did not want to expose his humiliated past in front of Sethe. However, when faced with the temptation and invasion from Beloved, his fort collapsed instantly. He rampantly tried to change the place of rest at home, but could find nowhere to put aside his past. In front of the wounds of the past, the strong man became weak and helpless. Jiajun Tao said in an analytical article named "Trauma", "the Beloved of the dead returned to the world opened a wound in the soul of each slaves, opened a black ethnic collective history and cultural memory hole full of deep wounds." [11] Here the hole is just the wound Sethe et all were trying to escape from. However the racial wounds, humiliation, destruction of body and mind in the past made them nowhere to hide.

\section{The Plight of Trauma Narrative}

After Sethe was hurt by racial trauma, she appeared PostTraumatic Stress Disorder, a typical symptom of racial trauma of which the victim feels reluctant to mention the traumatic experience. But once the victim starts to recall, he/ she will constantly repeat. Trauma in this case can be experienced at least in two ways: Firstly, inability to integrate into their own memory of past experience. Secondly inability to exchange 
disastrous knowledge with others. On the one hand Sethe is separated from her traumatic experience, which is external object-oriented; on the other hand she kept her traumatic experience to herself, avoiding exchange with the outside world. The two extremes in thoughts showed 2 totally different behaviours, silence or repeatedly murmuring of the past.

\subsection{Silence}

When talking with Denver Sethe manifested her struggling in thought: on one hand she doesn't want to mention the very miserable experience, and on the other hand she wants to keep her daughter away from the cruelty of slavery.

Denver was curious and always wanted to ask about the past. The two kept a Question \& Answer way, i.e. Sethe only passively answered Denver's questions, and often stopped in the middle. When talking about her love story with Hale, she became talkative and there're length description in the novel; but when she was asked where her earrings are gone, Sethe stopped immediately, she said, 'They took them from me' . 'The men without skin took them' 'yes I was going to help you but the clouds got in the way' [12] ... and then she would not say a word. In fact, Sethe lost her earrings in jail when she was convicted for the killing of children. Sethe stopped this narrative deliberately to avoid traumatic memory.

"Denver knew that her mother was through with it - for now anyway. The single slow blink of her eyes; the bottom lip sliding up slowly to cover the top; and then a nostril sigh, like the snuff of a candle flame - signs that Sethe had reached the point beyond which she would not go. "[13] when it came to trauma, Sethe would halt abruptly, and this was to instinctively avoid memories of the past. Sethe tried to control herself, not let Denver know about the terrible slavery life. She believed she had the responsibility to make Denver away from her past. Her unique maternal love kept her a strong sense of responsibility to protect any influence upon Denver away from slavery.

\subsection{Repeated Murmuring}

Repeated Murmuring about the traumatic scene is another side of her symptoms, which constantly forced Sethe experience trauma again. "Post-Traumatic Stress Disorder (PTSD) --- in which the overwhelming events of the past repeatedly possess, in intrusive images and thoughts, the one who has lived through them. This singular possession by the past... extends beyond the bounds of a marginal pathology and has become a central characteristic of the survivor experience of our time." [14] Sethe could not clearly distinguish between past and present, memory and trauma overlapped and intertwined in daily life, past traumatic experiences occupied Seth's mind and dominated her spiritual world, disrupting Sethe of rational thinking, resulting in confusion in memory.

Traumatic memory does not belong to the usual narrative or speech memories mechanism, instead it manifests in human perception, repeated behaviour and nightmare. In the novel, everyday Sethe's most important thing is to drive away past. Fragmented memories reflect the most hurting event to Sethe. In the novel the scene that a white man grabbed her milk away flashed 5 times, and she repeated three times in her dialogue; since Paul - D told Sethe Hale was driven crazy because he witnessed the white man sucking her milk. The scene that Hale was driven crazy appeared at least three times; when she found that Beloved was just the kid she had killed, Sethe kept explaining her behaviour with almost irrational reasons, this "strong expression of desire, constantly repetitive trauma narrative associated with the traumatic event or events to do is a common symptom of trauma." [15] Every traumatic event caused a shock to Sethe, and every event repeated again and again which even stimulated her behaviour more. According to Sigmund Freud, if a person can not cope with an intense emotional experience, the results will cause the neuropathy. Wounds of the past in a variety of repeated forms seems to replace the entire current world, becoming forever occupied Sethe in memory and consciousness, which separated Sethe's from her subjective self-consciousness, is a dissociation. "Dissociation is closely related with trauma...is viewed as an adaptive response to overwhelming and inescapable threat or trauma. In effect, the victim escapes by walling off distressing experiences and memories or retreating to a corner of his or her mind" [16] In the story Sethe is an experiencer, and when she talked about traumatic experiences she is also a survivor. This negatively impacted her nerve system and finally caused breakdown between thoughts, emotion and behaviour, i.e. schizophrenia. Re-memory of the past constantly repeated harassment, the impact of the trauma has evolved into a disease. Beloved crazily revenged Sethe, asking for maternal love, and thin and tiny Sethe shrank in the corner repeating why she killed beloved. She wouldn't even think of why she needed to explain and whether the explanation helped or not. "Dissociation" behaviour hindered Sethe to integrate her memory, identity and experience, destroyed Sethe's cognitive system, a sense of revenge on the murderer continued to promote awareness and illogical culminated her trauma symptoms and out-broke.

Black slave Sethe and her family struggled in the abyss of slavery history and it's so hard to get rid of ethnicity trauma. Escaping from trauma and replay of traumatic memories intertwined. But struggling with history is always futile, Toni Morrison tried to explore ways to be more effective in repairing racial wounds: Confront the history, face reality.

\section{References}

[1] Su, Chen. Replay the history of trauma: Swift, Graham Novel Study [M]. Suzhou, Suzhou University Press, 2009: 17.

[2] Toni Morrison, Beloved, First Vintage International Edition, June 2004: 243-244.

[3] Cathy Caruth. Trauma: Explorations in Memory [C]. Lodon: The johns Hopkins University Press, 1995: viii. 
[4] Toni Morrison, Beloved, First Vintage International Edition, June 2004: 243-245.

[5] Toni Morrison, Beloved, First Vintage International Edition, June 2004: 49.

[6] Toni Morrison, Beloved, First Vintage International Edition, June 2004: 258

[7] Morrison, Toni \& Danille Taylor-Guthrie. Conversations with Toni Morrison. Jackson: UP of Mississippi, 1994: 257.

[8] Morrison, Toni \& Danille Taylor-Guthrie. Conversations with Toni Morrison. Jackson: UP of Mississippi, 1994: 247,

[9] William L. Andrews and Mckay. Nellie Y.ed. Toni Morrison's "Bloved": A Casebook [C]. Oxford: Oxford University Press, 1999: 3 .
[10] Tao, Jiajun. Trauma [J]. Foreign Literature, 2011 (4).

[11] Toni Morrison, Beloved, First Vintage International Edition, June 2004: 254-256,

[12] Toni Morrison, Beloved, First Vintage International Edition, June 2004: 45.

[13] Cathy Caruth, Trauma Explorations in Memory, The Johns and Hopkins University Press, Baltimore and London, 1995: 151 .

[14] Li, Guirong. Trauma narrative: a study of Anthony Burgess trauma literature [M]. Beijing: Intellectual Property Publishing House, 2010: 30 .

[15] Paul Antze and Michael Lambek.Tense Past: Cultural Essays in Trauma and Memory [C]. New York and London: Routledge, 1996: 179. 